\title{
Foreign Relations Law As a Bargaining Tool?
}

\author{
Felix Lange
}

\section{INTRODUCTION}

To perceive foreign relations law as a self-standing academic subfield, perspective or theme which enlightens our understanding of the linkages between national and international law is a rather novel phenomenon. ${ }^{1}$ In most jurisdictions an academic tradition of foreign relations law as a separate field or theme does not exist. Issues of foreign relations law such as the separation of powers in foreign affairs or the integration of international law into the domestic order are often either discussed in treatises of constitutional or international law, or in both. For instance, not only the Oxford Handbook of the Indian Constitution contains a chapter on the case law of the Indian Supreme Court dealing with the status of international law in the Indian legal system ${ }^{2}$ but also the edited volume Comparative International Law includes a contribution addressing how the Indian Supreme Court integrates human rights law into the domestic order. ${ }^{3}$ Moreover, if, like in the United States, a foreign relations law tradition exists, the norms of the US Constitution and the case law of the Supreme Court which relate to foreign affairs are often taught and analyzed by scholars who teach and write on international and domestic

1 Curtis A. Bradley (ed.), The Oxford Handbook of Comparative Foreign Relations Law (New York: Oxford University Press, 2019).

2 The chapter also addresses the division of competences between the executive and legislature, Lavanya Rajamani, 'International Law and the Constitutional Schema', in Sujit Choudhry, Madhav Khosla and Pratab Bhani Mehta (eds.), The Oxford Handbook of the Indian Constitution (New York: Oxford University Press, 2016), p. 143.

3 Neha Jain, "The Democratizing Force of International Law: Human Rights Adjudication by the Indian Supreme Court', in Anthea Roberts et al. (eds.), Comparative International Law (New York: Oxford University Press, 2018), p. 319. 
(constitutional) law. ${ }^{4}$ As the editors of this volume rightly emphasize, foreign relations law thus concerns the relationship between domestic (constitutional) law and international law. The hybrid character of foreign relations law invites us to ponder about the repercussions of domestic (constitutional) law for international law and vice versa. ${ }^{5}$

This contribution attempts to shed some light onto the issue of the place of foreign relations law and the bridges and boundaries it builds between constitutional and international law. It starts by studying the emergence of foreign relations law in various jurisdictions and its relationship to domestic (constitutional) law and international law. It argues that foreign relations law is best understood as a subfield or theme of domestic (constitutional) law with close linkages to international law.

But seeing the locus of foreign relations law in the domestic is only the starting point for a broader engagement with its effects on international law and vice versa. In general, the separation of foreign relations law from international law should not make us blind for studying the interlinkages and impacts of the respective fields on each other. For instance, the study of the informal and contextual influence of foreign relations law on international treaty-making seems to be worthwhile.

Therefore, this contribution analyzes one aspect of the informal use of foreign relations law in relation to international law: it discusses the possibility to rely on domestic foreign relations law as a bargaining tool in international negotiations to persuade the other negotiating parties of one's own perspective. Domestic foreign relations law might shape the negotiation process and limit possible outcomes if one actor successfully flags a certain negotiating outcome as leading to nonparticipation because of domestic veto powers. If the historic role of veto powers in treaty-making makes the threat of nonparticipation credible, the other negotiating parties might be tempted to give in and sign onto the other side's negotiating goal.

In particular, I study the evolution of the bargaining position of the United States in relation to the Paris Agreement on climate change and its connection to US foreign relations law. In the debate about the Paris Agreement, the Obama administration highlighted that the domestic constitutional rules on treaty-making call for negotiating a treaty with nonbinding provisions on climate change mitigation. Notably, the US delegation successfully stopped

4 See for instance bio of Curtis Bradley, https://law.duke.edu/fac/bradleyc/; Jack Goldsmith, https://hls.harvard.edu/faculty/directory/10320/Goldsmith; Oona Hathaway, https://law .yale.edu/oona-hathaway, accessed September 30, 2020.

5 Helmut Philipp Aust and Thomas Kleinlein, 'Introduction', this volume. 
the adoption of a pre-negotiated final document containing language which sounded like binding commitments on climate mitigation by pointing to its foreign relations law. As I demonstrate, US foreign relations law indeed places considerable constraints on executive treaty-making without involvement of the Senate or Congress. The history of the discussions on the United Nations Framework Convention on Climate Change and the Kyoto Protocol shows that various actors regarded Senate involvement for treaties concerning climate change mitigation as obligatory. ${ }^{6}$ However, it is also important to be aware of the ambivalence of the foreign relations law on the matter and the restraint of US courts to judicialize foreign affairs. Arguably, the Obama administration did not exhaust interpretations of its foreign relations law allowing more binding-sounding language on climate mitigation because the negotiating team itself was not eager to commit to binding language. ${ }^{7}$ US negotiators also favored nonbinding commitments on climate mitigation for developed countries because they intended to prevent a scheme differentiating between developed and developing countries. ${ }^{8}$ In this sense, US foreign relations law became the bargaining tool which limited the space of potential negotiating outcomes on the international plane and allowed the Obama administration to achieve the result it wanted. Even though foreign relations law can unfold this power only under very specific circumstances, the example demonstrates the potential effects of domestic constitutional design for the international legal structure.

\section{THE EMERGENCE OF FOREIGN RELATIONS LAW AND ITS RELATIONSHIP TO INTERNATIONAL LAW}

The design of the constitutional rules addressing foreign affairs has always been an important issue during the constitution-making processes in constitutional democracies. Building on enlightenment philosophers like John Locke, ${ }^{9}$ the founding fathers of the US Constitution debated how to allocate the competences between the branches of government in foreign affairs and the role of international treaty and customary law in the domestic legal order. ${ }^{10}$ In the British public law tradition, William Blackstone and Albert Venn Dicey

\footnotetext{
See below III.B and C.

See below III.C.

See below III.C.

John Locke, Second Treatise of Civil Government (169o), s. 147.

10 For instance, The Federalist Papers No. 75, Publius (Alexander Hamilton), "The TreatyMaking Power of the Executive', 1788, https://avalon.law.yale.edu/18th_century/fed 75 .asp, accessed September 30, 2020.
} 
contributed to an understanding of foreign affairs law as an area of executive dominance and discretion by highlighting the powers of the Crown. ${ }^{11}$ Also, in the constitution-making processes of the nineteenth century, the emerging constitutional democracies opted for different models concerning the allocation of the foreign affairs power. ${ }^{12}$

The legal sciences, however, did not start to become systematically interested in issues of foreign relations law until the early twentieth century. In the United States, Quincy Wright's 1922 study on The Control of American Foreign Relations set the tone for the US debate on the constitutional implications for foreign affairs. ${ }^{13}$ His discussion of the enforcement of international law in domestic courts and the powers of the President and Congress on international treaty-making and implementation, is still today regarded as an important predecessor of the contemporary debate in the United States. ${ }^{14}$ One year later, Ernst Wolgast published his in-depth analysis of the 'Foreign Power' (Auswärtige Gewalt) of the German Reich addressing similar issues for the Weimar constitutional system. ${ }^{15}$

After the Second World War, the topic continued to stay relevant in particular in the US debate. During the 1940s, the increasing international engagement of the United States led to the emergence of congressionalexecutive agreements in constitutional practice causing a scholarly boom on the topic. ${ }^{16}$ The term 'foreign relations law' developed to distinguish a separate field of study from international law and constitutional law stricto sensu analyzing the separation of powers in foreign affairs, the integration of international law in the US legal system and the international law applicable to the United States. ${ }^{17}$ In 1965 , the American Law Institute published the

1 William Blackstone, Commentaries on the Laws of England, 4 vols. (Oxford: Clarendon Press, 1765), vol. I, p. 245; Albert V. Dicey, Introduction to the Study of the Law of the Constitution (London: Macmillan, 1885), p. 465.

12 See Robert Schütze, Foreign Affairs and the EU Constitution: Selected Essays (Cambridge: Cambridge University Press, 2014), p. 361.

13 Quincy Wright, The Control of American Foreign Relations (New York: Macmillan, 1922).

14 Curtis A. Bradley, International Law in the U.S. Legal System, 2nd ed., (New York: Oxford University Press, 2015), Preface.

15 Ernst Wolgast, 'Die auswärtige Gewalt des Deutschen Reiches unter besonderer Berücksichtigung des Auswärtigen Amtes' (1923) 44 Archiv des öffentlichen Rechts 1.

16 See for instance Quincy Wright, 'The United States and International Agreements' (1944) 38 AJIL 341; Myres S. McDougal and Asher Lans, "Treaties and Congressional-Executive or Presidential Agreements: Interchangeable Instruments of National Policy (pts. I and II)' (1945) 54 Yale Law Journal 181 and 534; Edwin Borchard, 'Treaties and Executive Agreements A Reply' (1945) 54 Yale Law Journal 616.

17 On the history of the concept see Curtis A. Bradley, 'What Is Foreign Relations Law?', in Curtis A. Bradley (ed.), The Oxford Handbook of Comparative Foreign Relations Law (New York: Oxford University Press, 2019), pp. 1 at 5-8. 
Restatement (Second) of Foreign Relations Law of the United States with a focus on these topics and thus contributed to the successful establishment of the theme as a disparate scholarly field. ${ }^{18}$ Around thirty years later, the scholarly consensus on issues of foreign affairs which had been enshrined in the 1987 Restatement (Third) of Foreign Relations Law of the United States with Louis Henkin as Chief Rapporteur was put into question. ${ }^{19}$ Some scholars challenged assumptions about the internationalization of the US legal system and triggered a flood of positive and hostile reactions in scholarship. ${ }^{20}$

In other constitutional democracies, the relationship between the constitution and the international legal order has also been a popular topic of academic debates. For instance, in 1954, Western German public law professors debated the division of competences between parliament and the executive in foreign affairs as well as between the federal and state level shaping the constitutional practice of the young German Federal Republic for years to come. ${ }^{21}$ Moreover, Klaus Vogel's 1964 programmatic essay on the internationalization of German constitutional law became a common reference point for future generations of scholars. ${ }^{22}$ The recent establishment of Staatsrecht III as a distinct class of the constitutional law curriculum then triggered a substantial increase in publications on the topic. ${ }^{23}$ In South Africa, the constitution-making in the 1990s spurred a debate about the relationship of the post-apartheid Constitution with international law. ${ }^{24}$ The theme is frequently taken up in reaction to international law-friendly judgments of South African courts. ${ }^{25}$ Also, the foreign relations law of supranational entities like

18 Restatement (Second) of the Foreign Relations Law of the United States (1965).

19 Restatement (Third) of the Foreign Relations Law of the United States (1987).

20 Seminal: Curtis A. Bradley and Jack L. Goldsmith, 'Customary International Law as Federal Common Law: A Critique of the Modern Position' (1997) 110 Harvard Law Review 815; for the new consensus see the partial revision in Restatement (Fourth) of the Foreign Relations Law of the United States (2018).

${ }^{21}$ Wilhelm Grewe and Eberhard Menzel, 'Die auswärtige Gewalt der Bundesrepublik' (1954) 12 Veröffentlichungen der Vereinigung der Deutschen Staatsrechtslehrer 129.

${ }^{22}$ Klaus Vogel, Die Verfassungsentscheidung des Grundgesetzes für eine internationale Zusammenarbeit (Tübingen: Mohr, 1964).

23 See for instance Frank Schorkopf, Staatsrecht der internationalen Beziehungen (München: Beck, 2017); Heiko Sauer, Staatsrecht III: Auswärtige Gewalt, Bezüge des Grundgesetzes zu Völker- und Europarecht (München: Beck, 2011); Christian Calliess, Staatsrecht III: Bezüge zum Völker-und Europarecht, 2nd ed. (München: Beck, 2018); Andreas Paulus, Staatsrecht III: Mit Bezügen zum Völker- und Europarecht (München: Beck, 2010).

24 John Dugard, 'International Law and the South African Constitution' (1997) 8 EJIL 77; Neville Botha, 'Treaty Making in South Africa: a Reassessment' (2000) 25 South African Yearbook of International Law 69.

25 Erika de Wet, "The "Friendly but Cautious" Reception of International Law in the Jurisprudence of the South African Constitutional Court: Some Critical Remarks' (2004) 28 
the European Union now receives academic attention. ${ }^{26}$ Even though the understanding that foreign relations law is a separate field in the legal sciences is rather the exception than the rule in constitutional democracies, scholarly attention has clearly been growing.

Furthermore, a recent comparative turn sparked the interest in foreign relations law in various jurisdictions. In 2011, Campbell McLachlan's study of foreign relations law in various Commonwealth states became a key building block for the scholarly field or theme. ${ }^{27}$ Also, the various chapters on manifold jurisdiction in the 2019 Oxford Handbook on Comparative Foreign Relations Law illustrate the rising scholarly interest. ${ }^{28}$

The maturation of foreign relations law as a disparate scholarly field or theme is accompanied by debates about its definition, place and function. In particular, various authors address the tricky relationship of foreign relations law to constitutional law and international law. The editor of the Oxford Handbook, Curtis Bradley, defines foreign relations law as 'the domestic law of each nation that governs how that nation interacts with the rest of the world'. ${ }^{29}$ For him, the theme encompasses the allocation of authority on the vertical and horizontal level of a state and the role of international law before domestic courts, but not “"pure" questions' of international law. ${ }^{30}$ Similarly, in the Max Planck Encyclopedia of Comparative Constitutional Law, Helmut Aust regards the separation of powers in foreign affairs, the rights of the individual when foreign relations are affected and the relationship between foreign affairs and democracy as key themes of foreign affairs law in the constitutional state. ${ }^{31}$ Thomas Giegerich stresses in his contribution for the Max Planck Encyclopedia of Public International Law that "[a]lthough the foreign relations law forms that part of internal law which is most closely interlinked with international law, it remains internal law'. For him, 'there is not one worldwide foreign relations law but there are many, however, that

Fordham International Law Journal 1529; Max du Plessis and Guénaël Mettraux, 'South Africa's Failed Withdrawal from the Rome Statute: Politics, Law, and Judicial Accountability' (2017) 15 Journal of International Criminal Justice 361; Dire Tladi, 'A Constitution Made for Mandela, A Constitutional Jurisprudence Developed for Zuma', this volume.

26 Marise Cremona and Bruno de Witte (eds.), EU Foreign Relations Law: Constitutional Fundamentals (Oxford/Portland: Hart Publishing, 2008); Schütze, Foreign Affairs.

27 Campbell McLachlan, Foreign Relations Law (Cambridge: Cambridge University Press, 2014).

28 Bradley, Comparative Foreign Relations Law.

29 Bradley, 'What Is Foreign Relations Law?', 3-4.

30 Bradley, 'What Is Foreign Relations Law?', 3-4.

${ }^{31}$ Helmut Philipp Aust, 'Foreign Affairs', in Max Planck Encyclopedia of Comparative Constitutional Law, August 2017, para. 5, https://oxcon.ouplaw.com/home/MPECCOL. 
share certain common principles'. ${ }^{32}$ Moreover, when foreign relations law is distinguished from related subfields like comparative international law, its domestic dimension is emphasized. As Anthea Roberts, Paul Stephan, PierreHugues Verdier and Mila Versteeg stress, comparative foreign relations law examines 'the rules, institutions, and practices in different states with respect to how that state conducts relations with foreign states and other actors', whereas comparative international law assesses the different national and regional approaches to and applications of international law. 33

Despite the grounding in domestic (constitutional) law, foreign relations law scholars are well aware of the links to international law. For some, international law is even part of foreign affairs law. In the US tradition, treatises of foreign relations law often contain chapters on the international legal rules relevant for the United States. According to Restatement the Third, foreign relations law draws its sources both from international law as applicable to the relevant state and national law, in particular constitutional law, governing that state's foreign relations. ${ }^{34}$ Therefore, Louis Henkin situates the subject of foreign affairs law as a scholarly endeavor 'somewhere between the constitutional lawyer and the international lawyer'. 35 Similarly, Campbell McLachlan emphasizes that foreign relations law sits at the "interface of international and municipal law' allocating jurisdiction between domestic or international courts and determining the division of competences between the three branches. ${ }^{36}$

The connections between international law and foreign relations law are manifold indeed, even if one assumes that foreign relations law is a subfield of domestic (constitutional) law in the respective jurisdictions and separate from international law. Doctrinal conjunctions as in article 46 VCLT $^{37}$ and as in the opening clauses of many constitutions (for instance article $51 \mathrm{c}$ of the Indian Constitution; section 39 (1b) of the South African Constitution) are evidence for the close interlinkages. In some sense, foreign relations law is the bridge builder between domestic law and international law.

32 Thomas Giegerich, 'Foreign Relations Law', in Max Planck Encyclopedia of Public International Law, January 2011, https://opil.ouplaw.com/home/mpil, para. 1.

33 Anthea Roberts et al., 'Conceptualizing Comparative International Law', in Anthea Roberts et al. (eds.), Comparative International Law (New York: Oxford University Press, 2018), p. 9.

34 Restatement (Third) of the Foreign Relations Law of the United States $\int 1$ (1987).

35 Louis Henkin, Foreign Affairs and the US Constitution (Oxford: Clarendon Press, 1996), p. viii.

$3^{6}$ McLachlan, Foreign Relations Law, pp. xxi, 18-30.

37 Vienna Convention on the Law of Treaties, Vienna, May 23, 1969, in force January 27, 1980, 1155 UNTS 331; (1969) 8 ILM 679; UKTS (1980) 58. See Aust and Kleinlein, 'Introduction', Section I; Edward T. Swaine, 'International Foreign Relations Law', this volume, Section I. 


\section{FOREIGN RELATIONS LAW AS A BARGAINING TOOL?}

Besides these doctrinal interconnections, an indirect and informal nexus between foreign relations law and international law exists. For instance, the domestic rules on treaty-making may shape how certain states negotiate international treaties and may have a substantial impact on the substantive content of a treaty. These contextual and informal linkages between foreign relations law and international law become evident when foreign relations law is used as a bargaining tool in international negotiations.

Theoretically, the possible usage of foreign relations law as a bargaining tool has been alluded to already at the end of the 1980s. The political scientist Robert Putnam is well-known for his two-level game theory in which he assesses the impact of domestic politics on international negotiations. ${ }^{38} \mathrm{On}$ the basis of a study of $\mathrm{G}_{7}$ summits, Putnam demonstrates how domestic interest groups affect the positions of the respective national governments in negotiations on the international level. ${ }^{39}$ In passing, Putnam suggests a promising negotiating strategy which links domestic politics with the international negotiations. A delegation should try to convince the other negotiating parties that its suggested draft will certainly be ratified in its own national legal system while a draft more favorable to the opponent will fail in the domestic ratification procedure. ${ }^{40}$ Putnam thus theoretically preconceives how foreign relations law could be used as a bargaining tool in international relations. A government should point to the risk of a potential veto from a domestic actor on an agreement which is in the general interest of all negotiating partners. If the government can make a credible claim that its domestic laws enable an actor to block the ratification and that the domestic actor is skeptical of the treaty arrangement, the other negotiating parties interested in collective participation in the treaty regime might accept the government's suggested draft as the only possible compromise.

Empirically, the impact of foreign relations law on international treaty negotiations is however not obvious. Because article 46 VCLT has never been successfully pleaded before an international court, ${ }^{41}$ the domestic constitutional design does not seem to have major relevance for the legality of

Robert D. Putnam, 'Diplomacy and Domestic Politics: The Logic of Two-Level Games' (1988) 42 International Organization 427.

39 Putnam, 'Diplomacy and Domestic Politics', 427.

$4 \circ$ Putnam, 'Diplomacy and Domestic Politics', 453.

${ }^{41}$ Hannah Woolaver, 'State Engagement with Treaties: Interactions between International and Domestic Law', in Curtis A. Bradley (ed.), The Oxford Handbook of Comparative Foreign Relations Law (New York: Oxford University Press, 2019), p. 431 at 435; see for example Land and Maritime Boundary between Cameroon and Nigeria (Cameroon v. Nigeria; Equitorial 
a treaty on the international level. Moreover, even if one assumes that negotiating partners are concerned about the prospects of ratification by the respective opposite side, it is hard to assess the credibility of the argument about foreign relations law. Competing accounts about the exact contours of a domestic foreign relations law in a particular country make the assessment of limits for domestic ratification rather challenging. ${ }^{42} \mathrm{Also}$, one has to touch unstable ground by making assumptions about future actions in the domestic ratification processes and envisaging a certain behavior by parliamentary veto players.

Nonetheless, this contribution argues that there exists some evidence that Putnam's envisioned strategy played a role in the context of the Paris climate change negotiations. The Obama administration successfully talked other states into adopting the US negotiating position on nonbinding commitments for climate change mitigation by pointing to its foreign relations law and potential veto players in the domestic context. Given the history of the UNFCCC and Kyoto negotiations, the Obama administration's argument about the necessity of senatorial involvement for subscribing to binding mitigation commitments was credible. However, this contribution also points to the ambivalences of US foreign relations law and highlights the reluctance of the US courts to weigh into foreign affairs. Against this background, the Obama administration arguably opted for a risk averse strategy when it comes to the nonbinding legal character of climate mitigation commitments because this was in line with another US negotiating goal to prevent a scheme which differentiates between developed and developing countries.

\section{A Treaty-Making under the US Constitution}

The foreign relations law of the United States establishes high hurdles for treaty participation. The US Constitution of 1789 heavily involves the Senate in the treaty-making process entailing a 'threshold [for approval of a treaty] higher than that in nearly all other advanced industrial democracies'. ${ }^{43}$ According to US Constitution, Article II $\mathbb{2}$, Clause 2, the President has the

Guinea Intervening), Judgment, I.C.J. Reports 2002, p. 303, 430-31, para. 265; on this see Swaine, this volume, Section I.

$4^{2}$ For instance, the debate on foreign relations law in the United States is characterized by strong divisions among the protagonists, for instance Peter J. Spiro, "The New Sovereigntists: American Exceptionalism and Its False Prophets' (2000) 79 Foreign Affairs 9.

43 Andrew Moravcsik, 'The Paradox of U.S. Human Rights Policy', in Michael Ignatieff (ed.), American Exceptionalism and Human Rights (Princeton: Princeton University Press, 2005), p. 187. 
power to conclude treaties with the 'Advice and Consent of the Senate' as long as 'two thirds of the Senators present concur'. The Founding Fathers bestowed the numerically smaller, expectedly more secretive Senate instead of the House of Representatives with this competence, also because Southern states regarded the senatorial blocking minority as safeguarding the US monopoly on navigation rights on the Mississippi River. ${ }^{44}$ On the basis of the article II procedure, administration officials usually negotiate the treaty and then ask the Senate for approval of the negotiated document. ${ }^{45}$ Some of the most important international agreements like the United Nations Charter, the NATO defence agreement, the Geneva Conventions, the Nuclear NonProliferation Treaty and a few human rights conventions have been concluded in this way. ${ }^{46}$

There exist various examples of international treaties which did not receive the consent of the Senate. Famously, the Senate did not support President Woodrow Wilson's attempt to join the Versailles Treaty after the First World War. ${ }^{47}$ Moreover, even though the Clinton and Obama administrations endorsed human rights treaties like the Convention on the Rights of the Child, the Convention on the Elimination of Discrimination Against Women and the Convention on the Rights of Disabled People, none of these treaties received the required senatorial consent. ${ }^{4}$ These experiences of domestic ratification failure make the threat of nonratification credible. It is quite realistic that an administration will not receive the required two-thirds majority in the Senate which has been called the 'graveyard'49 or 'cold storage $^{\text {'50 }}$ for international treaties.

However, according to US constitutional practice not every agreement negotiated at the international plane needs to follow the article II procedure in order to be ratified. Since the 1940s, so-called congressional-executive agreements emerged allowing for treaty participation of the United States

44 On this Oona A. Hathaway, 'Treaties' End: The Past, Present, and Future of International Lawmaking in the United States' (2008) 117 Yale Law Journal 1236 at 1278-86.

45 On the demise of the advice-criterion in the early US constitutional history, see Curtis A. Bradley and Martin S. Flaherty, 'Executive Power Essentialism and Foreign Affairs' (2004) 102 Michigan Law Review 545 at 626-31.

$4^{6}$ See Bradley, International Law in the U.S. Legal System, p. 84.

47 Thirty-nine senators voted in favor, fifty-five against.

$4^{8}$ For the US record on human rights see United Nations, Human Rights, Office of the High Commissioner, Ratification Status for United States of America, https://tbinternet.ohchr.org /_layouts/15/TreatyBodyExternal/Treaty.aspx, accessed September 30, 2020.

49 Covey T. Oliver, 'Getting the Senators to Accept the Reference of Treaties to Both Houses for Approval by Simple Majorities' (1980) 74 AJIL 142 at 143.

50 Louis Henkin, 'Treaties in a Constitutional Democracy' (1989) 10 Michigan Journal of International Law 406 at 411. 
without requiring the high threshold in the Senate. For such congressionalexecutive agreements, the President needs advance authorization or subsequent approval of a simple majority in Congress. ${ }^{51} \mathrm{~A}$ rising number of congressional-executive agreements have been completed in issue areas like trade, commerce and finance..$^{2}$ Moreover, sole executive agreements, which concern more technical issues, can be concluded by the President alone. Even though the US Constitution does not explicitly refer to executive agreements, ${ }^{53}$ the Supreme Court stated in dicta that the President has the power to make such international agreements as do not constitute treaties in the constitutional sense'54 and implicitly held such agreements to be valid. 55 According to the Case-Zablocki Act, the Secretary of State needs to submit every international agreement except for article II treaties within sixty days to Congress. ${ }^{56}$

How to distinguish between article II treaties, congressional-executive agreements and executive agreements remains a controversial question. The position enshrined in Restatement the Third ' $\mathrm{t}$ ] he prevailing view is that the Congressional-Executive agreement may be used as an alternative to the treaty method in every instance'57 found some support, but has also been challenged by various authors. ${ }^{8}$ The State Department relies on the Circular 175 procedure evaluating the agreement's impact on the US as a whole and on state laws, past US and international practice in relation to similar agreements, the preference of Congress, the duration as well as the desired formal character and expediency of the agreement. ${ }^{59}$ These criteria are not entirely clear-cut, lend themselves to interpretation and thus allow for some political discretion

51 Bradley, International Law in the U.S. Legal System, pp. 79-83.

52 See John Yoo, 'Rational Treaties: Article II, Congressional-Executive Agreements, and International Bargaining' (2011) 97 Cornell Law Review 1 at 2.

53 The Constitution refers to treaties, agreements and compacts, see for instance US Constitution Article I Section 10; Article II Section 2, Clause 2.

54 United States v. Curtiss-Wright Export Corp., 299 US 304, 318 (1936).

55 See for instance United States v. Guy W. Capps., Inc., 348 US 296 (1955); Dames \& Moore v. Regan, 453 US 654 (1981); American Ins. Ass'n v. Garamendi, 539 US 396 (2003).

$56 \quad$ USC $\$ 112 b$ (1994).

57 Restatement (Third) of the Foreign Relations Law of the United States $\$ 303$, Comment e (1987).

$5^{8}$ For support see Hathaway, 'Treaties' End', 1236; David M. Golove, 'Against Free-Form Formalism' (1998) 73 New York University Law Review 1791; for critique see Laurence H. Tribe, 'Taking Text and Structure Seriously: Reflections on Free-Form Method in Constitutional Interpretation' (1995) 108 Harvard Law Review 1221 at 1249-78; John C. Yoo, 'Laws as Treaties?: The Constitutionality of Congressional-Executive Agreements' (2001) 99 Michigan Law Review 757 at 776.

59 11 FAM 720, Negotiation and Conclusion, September 25, 2006, https://fam.state.gov/fam/11f am/11famo $720 . h$ tml, accessed September 30, 2020 . 
for each administration. More importantly, the US Supreme Court has been rather reluctant to adjudicate in foreign relations leaving it to Congress and the President to solve the dispute politically. For instance, the Court denied granting certiorari to the case challenging the conclusion of NAFTA as a congressional-executive agreement after the US Court of Appeals of the 11th circuit had dismissed the case as nonjusticiable on the basis of the political question doctrine. ${ }^{60}$ Therefore, US courts did not develop strict limits on how to categorize certain agreements negotiated at the international level. This means that as long as there is no adjudicator to check the classification of the administration, the respective administrations possess some leeway on whether a certain agreement is an article II treaty, a congressional-executive agreement or a sole executive agreement.

\section{B The Obama Administration and Nonbindingness of Climate Mitigation Commitments}

The classifications of different types of agreements had a strong impact on the US position on the Paris Agreement. From the beginning of the negotiations, the administration posited that it intended an agreement with nonbinding language on climate change mitigation. More than a year before COP 21 in Paris, Todd Stern, the chief US negotiator of the Paris Agreement, stressed that 'the new agreement will be a legally binding one in at least some respects, but doesn't specify which ones'. He highlighted that the US supported a proposal by New Zealand according to which 'there would be a legally binding obligation to submit a "schedule" for reducing emissions, plus various legally binding provisions for accounting, reporting, review, periodic updating of the schedules, etc. But the content of the schedule itself would not be legally binding at an international level'. ${ }^{61}$ One month prior to the Paris meeting, Secretary of State John Kerry told the Financial Times that the Paris climate negotiations would not lead to a treaty legally requiring reductions of carbon emissions and would be different from the Kyoto Protocol. ${ }^{62}$ Moreover, when the US submitted its intended nationally determined contributions to

60 Made in the USA Foundation v. United States, 242 F 3d 1300 (11th Cir. 2001), cert. denied, 534 US 1039 (2001).

61 Todd D. Stern, 'Seizing the Opportunity for Progress on Climate', US Department of State, October 14, 2014, https://2009-2017.state.gov/s/climate/releases/2014/232962.htm, accessed September 30, 2020.

62 Demetri Sevastopulo and Pilita Clark, 'Paris Climate Deal Will Not Be a Legally Binding Treaty', Financial Times, November 11, 2015, www.ft.com/content/79daf872-8894-11e5-9ode-

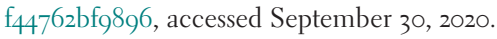


demonstrate its commitment to climate change mitigation before COP 21 in Paris, it did not refer to these contributions as being legally binding. ${ }^{6} 3$ The US delegation even explicitly rejected proposals by the European Union and small island states calling for the legal bindingness of nationally determined contributions. According to US negotiators, this would prevent high participation with and ambition within the agreement. ${ }^{64}$

The US delegation was even willing to risk the adoption of the negotiated document over the issue of the legal character of climate change mitigation commitments. Article 4 (4) of the final circulating draft held that '[d] eveloped country Parties shall continue taking the lead by undertaking economy-wide absolute emission reduction targets. Developing country Parties should continue enhancing their mitigation efforts, and are encouraged to move over time towards economy-wide emission reduction or limitation targets in the light of different national circumstances. ${ }^{65}$ Article 4 (4) thus clearly distinguished between the obligations of developed and developing countries.

This version of the Paris Agreement was not acceptable for the US delegation. John Kerry threatened that the US would not support the deal if the 'shall' would not be changed to 'should'. 66 According to the US delegation, the wording was smuggled into the final draft at the last minute despite the US rejection of such proposals in earlier drafts. ${ }^{6}$ In contrast, the delegations of some developing countries claimed that the 'shall' was the agreed language and the US challenge represented an unfair last minute move to better the US position crossing a red

63 United States, Intended National Determined Contributions, March 31, 2015, www4 .unfccc.int/sites/submissions/INDC/Published\%zoDocuments/United\%2oStates\% 20of\% zoA merica/1/U.S.\%2oCover\%zoNote\%zoINDC\%zoand\%zoAccompanying\%zoInformation.pdf, accessed September 30, 2020.

64 Daniel Bodansky, 'The Paris Climate Change Agreement: A New Hope?' (2016) 110 AJIL 288 at 297 .

65 Adoption of the Paris Agreement, Proposal of the President, Draft Decision, FCCC/CP/2015/ L.9, December 12, 2015, p. 21, https://unfccc.int/resource/docs/2015/cop21/eng/log.pdf, accessed September 30, 2020. Emphasis added.

66 John Kerry, Press Availability, US Department of State, December 12, 2015, https://2009-2017 .state.gov/secretary/remarks/2015/12/250590.htm, accessed September 30, 2020; see also Lisa Friedman, "How the World Solved the "Shall" Crisis and Reached a New Climate Accord,' E\&E News, December 14, 2015, www.eenews.net/stories/1060029452, accessed September 30, 2020; Melissa Eddy, 'At Climate Talks, a Few Letters That Almost Sank the Deal', The New York Times, December 14, 2015, www.nytimes.com/interactive/projects/cp/ climate/2015-paris-climate-talks/at-climate-talks-three-letters-almost-sunk-the-deal, accessed September 30, 2020; John Vidal, 'How a "Typo" Nearly Derailed the Paris Climate Deal', The Guardian, December 16, 2015, www.theguardian.com/environment/blog/2015/dec/16/ho w-a-typo-nearly-derailed-the-paris-climate-deal, accessed September 30, 2020.

67 On this Daniel Bodansky, 'Reflections on the Paris Conference', Opinio Juris, December 15, 2015, http://opiniojuris.org/2015/12/15/reflections-on-the-paris-conference/, accessed September 30,2020 . 
line on differentiation between developing and developed countries. ${ }^{68}$ In any case, the French Presidency around Laurent Fabius yielded to the American concerns in order to save the adoption of the Paris Agreement. The Secretariat declared the 'shall' to stem from a typographical error. States thus could vote on the basis of a corrected final version incorporating the 'should' and no new negotiating around delaying the adoption had to be opened. ${ }^{69}$

According to the Obama administration, the key reason for why the US insisted on (re-)introducing the nonbinding 'should' into article 4 (4) of the Paris Agreement was US foreign relations law. In this view, the wording of article 4 (4) determined which actors had to be involved in the treaty-making process on the domestic level. After the adoption of the Paris Agreement, Kerry linked the drafting of article 4 (4) to the treaty-making procedure at home. In a press release, he celebrated having 'a binding agreement with respect to transparency and not having binding targets with respect to emissions or finance' as the achievement of key US negotiating goals. Otherwise 'a different kind of agreement' would have been necessary. ${ }^{70}$ Kerry also emphasized that by correcting the perceived mistake in relation to the drafting of article 4 (4), the US 'kept faith with our own negotiating standards and what we promised to Congress and the American people'. ${ }^{71}$ In an interview, Kerry adopted the argument of a US senator that 'this [agreement] doesn't need to be approved by the Congress because it doesn't have mandatory targets for reduction, and it doesn't have an enforcement-compliance mechanism'. ${ }^{72}$ Other senior administration officials became even more explicit about the link with US foreign relations law. In a background briefing on the Paris Agreement, officials of the State Department stressed that the notion of the targets not being binding was really a fundamental part of our approach from early on' because only such an agreement does not need to be submitted to the Senate. ${ }^{73}$ According to press reports, US diplomats were confident that the Senate did not need to be involved because the targets are nonbinding and

Vidal, 'How a "Typo" Nearly Derailed the Paris Climate Deal'; Meena Raman and Hilary Chiew, 'Paris Agreement Adopted after Last Minute “Technical Corrections", Third World Network, December 15, 2015, https:/twnetwork.org/climate-change/paris-agreement-adoptedafter-last-minute-\%ez\%80\% g8technical-corrections\%ez\%80\%99-o, accessed September 30, 2020.

69 Vidal, 'How a "Typo" Nearly Derailed the Paris Climate Deal.'

70 Kerry, Press Availability.

${ }^{71}$ Kerry, Press Availability.

$7^{2}$ John Kerry, Interview with Chris Wallace of FOX, US Department of State, December 12, 2015, https://2009-2017.state.gov/secretary/remarks/2015/12/250595.htm, accessed September 30, 2020.

73 Background Briefing on the Paris Climate Agreement, US Department of State, December 12, 2015, https://2009-2017.state.gov/r/pa/prs/ps/2015/12/250592.htm, accessed September 30, 2020. 
' $\mathrm{t}$ ] he elements that are binding are consistent with already approved previous agreements'. ${ }^{74}$ In this reading, only by replacing the 'shall' with the 'should', the Senate did not have to be involved in the treaty-making process.

Moreover, the US negotiators successfully inserted the foreign relations law argument in the international debate and thus limited the potential outcome of the negotiations. Some months before COP 21, French Minister of Foreign Affairs Laurent Fabius stated in a discussion with African delegates at UN climate talks that "we know the politics in the US. Whether we like it or not, if it comes to the Congress, they will refuse'. Fabius added that ' $[w]$ e must find a formula which is valuable for everybody and valuable for the US without going to the Congress' ${ }^{75}$ In the run-up to the final negotiations in Paris, EU Climate Commissioner Miguel Arias Cañete stressed that "[w]e need the United States on board, and we have to find a solution. ... We understand the concerns they have because of the political situation they have in the Congress'. ${ }^{76}$ Also in the context of the language on article 4 (4) Paris Agreement, the foreign relations law argument was crucial. According to the spokesperson for the Like-Minded Developing Countries, the EU approached the Group of Like-Minded Developing Countries and lobbied for acceptance of the last minute change citing US concerns about the involvement of the US Congress. ${ }^{77}$ The EU apparently internalized the US foreign relations law argument and relied on it in order to keep the US in the agreement. According to some observers, the US negotiators thereby made 'the world accept the domestic constraints in the United States as a feature of international climate talks'. ${ }^{8}$

\section{Between Real Risks and Bargaining Tool}

But how plausible was the argument of the Obama administration? Was the US negotiating position determined by domestic constraints?

74 Ed King, 'Paris Agreement "Does Not Need Senate Approval" Say Officials', Climate Home News, December 15, 2015, www.climatechangenews.com/2015/12/15/paris-agreement-does-not -need-senate-approval-say-officials/, accessed September 30, 2020.

75 Associated Press, 'Climate Deal Must Avoid US Congress Approval, French Minister Says', The Guardian, June 1, 2015, www.theguardian.com/world/2015/jun/o1/un-climate-talks-dealus-congress, accessed September 30, 2020.

$7^{6}$ Valerie Richardson, 'Republicans Move to Undermine Obama on Paris Climate Deal', The Washington Times, December 7, 2015, www.washingtontimes.com/news/2015/dec/7/repub licans-move-to-undermine-obama-on-paris-clima/, accessed September 30, 2020.

77 Raman and Chiew, 'Paris Agreement Adopted after Last Minute "Technical Corrections".

$7^{8}$ Raymond Clémençon, "The Two Sides of the Paris Climate Agreement: Dismal Failure or Historic Breakthrough?' (2016) 25 The Journal of Environment \& Development 3 at 6. 
It is no question that the involvement of the Senate in the treaty-making process would have placed a hurdle on the ratification of the Paris Agreement which could hardly be overcome. Since the ratification of the United Nations Framework Convention on Climate Change, the Senate had taken a skeptical position towards committing to more assertive climate mitigation obligations on the international level. While the Clinton administration negotiated the Kyoto Protocol, the Senate adopted the (nonbinding) Byrd-Hagel Resolution. With ninety-five to zero votes, the senators emphasized that the United States should not be a signatory to any protocol which would (A) mandate new commitments to limit or reduce greenhouse gas emissions for the Annex I Parties, unless the protocol also mandates new specific scheduled commitment for Developing Country Parties within the same compliance period, or (B) result in serious harm to the economy of the United States. ${ }^{79}$ By unanimously ruling out senatorial support for an agreement which differentiated in its legal bindingness for targets on greenhouse gas emission reductions between developed and developing countries, the senators put considerable pressure on the negotiating position of the administration. When after an intervention of Vice-President Al Gore the Clinton administration accepted a differentiation scheme between developed and developing countries, ${ }^{80}$ it was obvious that the chances for passing the domestic treaty-making process were slim. It was thus no surprise that the Clinton administration did not submit the Kyoto Protocol to the Senate after signing the protocol in November $1998{ }^{81}$ The Senate was regarded as the dead end of the Kyoto Protocol.

In relation to the Paris Agreement, the chances for the acceptance of a binding mitigation scheme did not look much brighter. Especially after the Republican successes at the midterm elections of 2014, Republican majorities in the Senate and the House of Representatives signalled that they would hardly support any policy initiatives of the Democratic President before the upcoming presidential elections. While the Obama administration was negotiating the Paris Agreement, the House and Senate adopted two resolutions which disputed the competences of the Environmental Protection Agency to

79 Byrd-Hagel Resolution, 105th Congress, 1st Session, S. RES. 98, https://web.archive.org/web/201 o.626110143/http://www.nationalcenter.org/KyotoSenate.html, accessed September 30, 2020.

8o Shardul Agrawala and Steinar Andresen, 'Indispensability and Indefensibility? The United States in the Climate Treaty Negotiations' (1999) 5 Global Governance 457 at 465.

81 CRS Report for Congress, 'Global Climate Change: Selected Legal Questions About the Kyoto Protocol', October 1, 2002, www.everycrsreport.com/files/20021001_98-349_75c808da e15c2gb2b5agf594598269e489f935ba.pdf, accessed September 30, 2020. 
regulate climate change emissions under the Clean Air Act and blocked the legal basis for such regulations. ${ }^{82}$ Republican Senator James M. Inhofe declared that the "message could not be more clear that Republicans and Democrats in both the U.S. Senate and U.S. House do not support the president's climate agenda, and the international community should take note'. ${ }^{8}$ Only a presidential veto in December 2015 against this resolution kept the door open for implementation of international commitments on climate change mitigation at the domestic level. ${ }^{84}$

Because of these voices and the history since the conclusion of the UNFCCC, the Obama administration knew that getting a climate treaty through the Senate was highly unrealistic. A key goal of the US delegation during the Paris climate change treaty negotiations was to ensure that the President would be able to bind the United States without seeking approval from the Senate or from Congress. Concluding the treaty as a sole executive agreement seemed to be the only promising way forward.

Moreover, a plausible argument can be made that binding commitments on climate change mitigation might have made involvement of the Senate necessary. Already during the domestic discussions on Senate approval of the UNFCCC in 1992, the domestic constitutional procedure for adopting future protocols had been discussed. In an answer to a question by the Senate Foreign Relations Committee, the Bush I administration stated that the article II procedure was needed, if a protocol adopting a targets and timetables scheme was negotiated and signed by the United States. ${ }^{85}$ The Senate Foreign Relations Committee also expressed its view that the introduction of legally binding emission targets would require the Senate's advice and consent. ${ }^{86}$ Accordingly, during the debate on the Kyoto Protocol with its binding scheme on targets and timetable, policy makers generally expected that senatorial advice and consent was a precondition for US ratification.

Therefore, US negotiators carefully tried to avoid resemblance with the Kyoto Protocol during the negotiations for a new agreement under the UNFCCC. In the context of the negotiations on the Copenhagen Accord,

$82 \quad$ S.J. Res. 23, 114th Cong. (2015); S.J. Res. 24, 114th Cong. (2015).

83 Richardson, 'Republicans Move to Undermine Obama on Paris Climate Deal.'

84 Barack Obama, 'Memorandum of Disapproval on S.J. Res. 23,' The White House, December 19, 2015, https://obamawhitehouse.archives.gov/the-press-office/2015/12/19/memo randum-disapproval-sj-res-23, accessed September 30, 2020.

85 UN Framework Convention on Climate Change, Hearing Before the Senate Committee on Foreign Relations, 102 Cong zd Sess. 1992, 106.

86 S. Exec. Rep. No. 102-55, at 14 (1992) reported by Mr. Pell. 
the US delegation suggested to use the term 'implementing agreement' for the new arrangement ${ }^{87}$ and was successful in convincing its negotiating partners to drop the term 'protocol'. ${ }^{88}$ Moreover, the Obama administration pushed against incorporating new financial commitments or legally binding emission targets in order to avoid involvement of the US Congress. ${ }^{89}$

Also, the domestic opposition was convinced that climate change mitigation obligations implied senatorial involvement, regardless of a legal or only political bindingness. In the run-up to the Paris negotiations, the Senate adopted a resolution expressing the sense of Congress that 'any agreement adopted at COP 21 containing targets and timetables, whether deemed "legally binding" or not, must be submitted to the Senate for advice and consent pursuant to Article II, section 2 of the Constitution. ${ }^{9 \circ}$ In reaction to the adoption of the Paris Agreement, Jim Inhofe emphasized that 'Senate leadership has already been outspoken in its positions that the United States is not legally bound to any agreement setting emissions targets or any financial commitment to it without approval by Congress'. ${ }^{91}$

But was foreign relations law so clear on the matter in particular when it comes to the wording of article 4 (4) Paris Agreement? Would a text stating that '[d]eveloped country Parties shall continue taking the lead by undertaking economy-wide absolute emission reduction targets' require the involvement of Congress?

Some observers like Dan Bodansky tend to adopt the argument of the Obama administration and put forward that 'arguably' the phrasing 'shall' would have made 'Senate or Congressional approval ... for US participation' necessary. ${ }^{92}$ However, as the 'arguably' signals, Bodansky is cautious not to present this legal position as the only possible view on the matter. Moreover, others have been more skeptical of the Obama administration's argument. For instance, before the conclusion of the Paris Agreement, David Wirth suggested that existing domestic federal laws and regulations allow international

US Submission on Copenhagen Agreed Outcome (2009), https:/unfccc.int/files/kyoto_proto col/application/pdf/usa040509.pdf, accessed September 30, 2020.

88 On this David A. Wirth, 'Cracking the American Climate Negotiators' Hidden Code: United States Law and the Paris Agreement' (2016) 6 Climate Law 152 at 155.

89 Bodansky, 'Hope', 297.

$9 \circ$ S. Con. Res. 25, Congressional Record Vol. 161, No 171, November 19, 2015, www.govinfo.gov/ content/pkg/CREC-2015-11-19/html/CREC-2015-11-19-pt1-PgS8166-2.htm, accessed September 30, 2020 .

91 Martin Pengelly, 'Obama Praises Paris Climate Deal As "Tribute to American Leadership", The Guardian, December 12, 2015, www.theguardian.com/us-news/2015/dec/12/obama-speech -paris-climate-change-talks-deal-american-leadership, accessed September 30, 2020.

$9^{2}$ Bodansky, 'Reflections on the Paris Conference.' 
legally binding commitments on emissions reductions. With reference to executive authority under the Clean Air Act and the precedent of the US signature of the Minamata Convention on Mercury, he put forward that 'neither Senate advice and consent nor new congressional legislation are necessarily conditions precedent to the United States becoming party to internationally binding mitigation commitments'. ${ }^{93}$ After the conclusion of the Paris Agreement, Wirth claimed that there is 'some - and perhaps considerable - room to argue' that enough domestic legal authority existed for subscribing to the 'shall' in article 4 (4) of the Paris Agreement. ${ }^{94}$ In particular, Wirth points to the ambiguous phrasing of the whole article 4 (4) of the Paris Agreement when it comes to legal bindingness (inter alia the wording 'undertaking' meaning to begin something or promise something). ${ }^{95}$

Even if one does not subscribe to this position, the scholarly controversy demonstrates that US foreign relations law is not definite on that matter. Consequently, the question arises who decides on the limits of the foreign affairs power. In contrast to other jurisdictions, the courts in the United States are known for not weighing in on matters of foreign affairs. Despite some debate about the 'normalization of foreign affairs' in the United States, ${ }^{96}$ the political question doctrine still is the law on the books, in particular in crucial matters of the separation of powers. As mentioned above, the Supreme Court did not hold hearing on a case concerning the distinction between article II treaties and congressional-executive agreements. ${ }^{97}$ Moreover, the Supreme Court did also not decide on the merits of a case concerning the competences for the withdrawal from article II treaties. ${ }^{9}$ Therefore, it is by no means certain that a US court would take up a legal challenge of the Paris Agreement containing the 'shall' on climate mitigation. It is telling that, despite some claims that the current Paris

David A. Wirth, "The International and Domestic Law of Climate Change: A Binding International Agreement Without the Senate or Congress?' (2015) 39 Harvard Environmental Law Review 515 at 517.

94 David A. Wirth, 'Cracking the American Climate Negotiators' Hidden Code: United States Law and the Paris Agreement' (2016) 6 Climate Law 152 at 167.

95 Wirth, 'Cracking the American Climate Negotiators' Hidden Code', 167; for a definition of 'to undertake' see https://dictionary.cambridge.org/dictionary/english/undertake, accessed September 30, 2020.

$9^{6}$ Ganesh Sitaraman and Ingrid Wuerth, 'The Normalization of Foreign Relations Law' (2015) 128 Harvard Law Review 1897; for a critique see Curtis A. Bradley, 'Foreign Relations Law and the Purported Shift Away From "Exceptionalism"” (2015) 128 Harvard Law Review Forum 294.

97 Made in the USA Foundation v. United States, $242 \mathrm{~F} 3 \mathrm{~d} 1300$ (11th Cir. 2001), cert. denied, 534 US 1039 (2001).

$9^{8}$ Goldwater v. Carter, 444 US 996 (1979). 
Agreement with the 'should' in article 4 (4) Paris Agreement violates US Constitution, Article II Section 2, Clause 2, ${ }^{99}$ the matter is (as far as I can see) not litigated before courts.

Moreover, the Obama administration's rejection of the 'shall' was not only due to its foreign relations law. The US delegation also intended to prevent a scheme which differentiated between developed and developing countries. Already during the discussions about the Kyoto Protocol, many actors in the United States had dismissed asymmetrical obligations on climate mitigation between developed and developing countries pointing to potential detrimental effects for the US economy. ${ }^{100}$ For developing countries, differentiation between binding mitigation commitments for developed countries and nonbinding rules for developing countries in the Kyoto Protocol had been a key objective expressing the principle of 'common but differentiated responsibilities' in the climate change regime. ${ }^{101}$ However, the US delegation was no longer willing to accept this. In the Paris negotiations, the rejection of a differentiated regime similar to the Kyoto Protocol was a key negotiating position of the US delegation. In October 2014, Todd Stern stressed that an inclusive agreement with broad participation was the main goal of the United States. ${ }^{102}$ In the context of the debate about article 4 (4) Paris Agreement, the Obama administration was concerned that the 'shall' created a distinction between binding obligations for developed countries and nonbinding obligations for developing countries. ${ }^{103}$ Accordingly, after the adoption of the agreement, the Obama administration celebrated that the agreement did not differentiate in such a way. ${ }^{104}$ Besides foreign relations law, the US negotiating team also had its own interest in nondifferentiation between all participants in the regime in mind.

\section{CONCLUSION}

This contribution demonstrates that under specific circumstances, domestic foreign relations law might have a substantial impact on international negotiations by narrowing the space for achievable outcomes.

99 Michael D. Ramsey, 'Evading the Treaty Power?: The Constitutionality of Nonbinding Agreements' (2016) 11 FIU Law Review 371 at 384-87.

100 See above III.B.

101 Lavanya Rajamani, 'Ambition and Differentiation in the 2015 Paris Agreement: Interpretative Possibilities and Underlying Politics’ (2016) 65 ICLQ 493 at 506.

102 Stern, 'Seizing the Opportunity for Progress on Climate'.

103 Raman and Chiew, 'Paris Agreement Adopted after Last Minute "Technical Corrections".'

104 Background Briefing on the Paris Climate Agreement. 
In the international discussions on the Paris Agreement, the US treatymaking procedure and potential veto players on the domestic level were the elephant in the room. Because the negotiating partners of the US feared that they would not get the United States on board if the Senate or Congress were involved in the domestic decision-making process, they accepted the Obama administration's insistence on nonbinding commitments for climate change mitigation. This does not mean that the Obama administration tricked its negotiating partners when referring to domestic constraints as an argument for replacing the 'shall' in article 4 (4) of the Paris Agreement with the 'should'. Given the history of nonratification of international climate treaties in the United States and the debate about binding commitments in the context of the UNFCCC, the necessity of congressional involvement for an agreement containing binding targets and timetables is plausible. Also, the risk of nonratification by the Senate and Congress was credible because of the Republican majorities in the parliamentary bodies.

However, it is important to point to the ambiguity of US foreign relations law on the matter and the reluctance of the US Supreme Court to judicialize foreign affairs. It seems not very likely that US courts would have decided on the treaty-making process in relation to the Paris Agreement even if the final version contained the 'shall' in article 4 (4). The Obama administration arguably opted for a risk-averse strategy when insisting on incorporating the 'should' in article 4 (4) of the Paris Agreement.

A potential reason for this strategy was that the Obama administration was interested in nonbinding commitments on climate change mitigation itself. Because the administration regarded equal treatment of developed and developing countries as a key negotiating goal, the US negotiators were not willing to accept a phrasing which distinguishes between a 'shall' for developed countries and a 'should' for developing countries. In this sense, foreign relations law provided a welcome argument as a bargaining tool to convince the negotiating partners to adopt the US position.

As this example shows, the potential use of foreign relations law as a bargaining tool is limited to very specific circumstances. It seems that a state can rely on its foreign relations law as a bargaining tool if two conditions are fulfilled. First, the participation of the state in a multilateral treaty is in the interest of all other potential treaty parties because the treaty enshrines a goal which can only be achieved in a cooperative spirit. Second, the state needs to credibly claim that a veto power in its domestic setting will prevent the ratification of the treaty if the treaty does not contain provisions with the preferred outcome for the state. 
The first criterion is more likely to apply to powerful states than to weaker states. Other parties probably are more interested in having China, India and the US on board as partners in a multilateral treaty regime than other small states. This is particularly true when the treaty addresses an issue to which bigger states contribute more than others. For instance, the US seems to be in a beneficial negotiating position in the climate change context because the participation of the world's second strongest emitter seems to be highly important for the success of the treaty's objectives.

The second criterion limits the use of foreign relations law as a bargaining tool to actors with a certain reputation. Given that the US Senate is widely perceived as the 'graveyard' or 'cold storage' for international treaties, the US seems to be the most likely actor to apply this negotiating strategy. In contrast, most states lack a veto player as strong as the Senate with a long history of nonratification of international treaties which makes the claim of potential nonratification credible. For instance, in India the executive alone decides which treaties it will conclude without involving parliament. In parliamentary systems like South Africa or Germany, the legislature most of the time supports the foreign policy approach of the government and approves negotiated treaties without much debate. Thus, the National Assembly and Bundestag are highly unlikely to act as a veto power.

However, also other states might point to constitutional constraints when they push for enshrining a certain rule in a treaty. It is telling that in the context of debates about how to respond to the Eurozone crisis in 2012, the head of the International Monetary Fund, Christine Lagarde, threatened to leave the room if she would hear 'Bundesverfassungsgericht' one more time. ${ }^{105}$ Apparently, Lagarde dismissed the argument by sceptics of the European rescue policies that a potential judgment by the German Constitutional Court might constrain the space for decision-making. Even though this example does not refer to the negotiation strategy of a state in international treaty negotiations, it demonstrates that constitutional limits might well become an argument in supra- and international debates, also outside of the US context.

Be it as it may, the Trump administration's actions in relation to the Paris Agreement are a far cry from using foreign relations law in international negotiations. The Trump administration signalled its intention to withdraw from the Paris Agreement in June 2017 and set in motion the year-long exiting

105 Kay-Alexander Scholz, 'Karlsruhe's Constitutional Monastery', Deutsche Welle, September 11, 2012, www.dw.com/en/karlsruhes-constitutional-monastery/a-16231161, accessed September 30, 2020. 
process in November 2019. ${ }^{106}$ Instead of influencing international negotiations with reference to domestic constraints, the Trump administration counts on its oil- and coal-friendly 'America First' policy.

However, it is interesting to see that the debate about the contours of foreign relations law also had repercussions for the withdrawal decision. When President Donald Trump renounced the Paris Agreement, he referred to 'serious legal and constitutional issues' since '[f]oreign leaders in Europe, Asia, and across the world should not have more to say with respect to the U.S. economy than our own citizens and their elected representatives' alluding to the noninvolvement of Congress. ${ }^{107}$ Even though every international treaty regime might, in the view of nationalists, introduce potential elements of influence of 'foreign' actors and raise 'constitutional issues', this might be particularly worrying if Congress has not been involved in the treaty-making in the first place. Moreover, the Obama administration's decision not to involve Congress also influenced the withdrawal decision more indirectly. Trump's decision to leave without involving Congress was hardly questioned on foreign relations law grounds. Since the Paris Agreement had been concluded as an executive agreement, most scholars agree that the executive alone could withdraw from the agreement. ${ }^{108}$ While US foreign relations law shaped the outcome of the Paris climate negotiations by limiting the space of potential outcomes, it did not constrain the executive decision-making process on the domestic level in the context of the withdrawal.

106 Emily Holden, "Trump Begins Year-Long Process to Formally Exit Paris Climate Agreement', The Guardian, November 5, 2019, www.theguardian.com/us-news/2019/nov/o4 /donald-trump-climate-crisis-exit-paris-agreement, accessed September 30, 2020.

107 Statement by President Trump on the Paris Climate Accord, The White House, June 1, 2017, www.whitehouse.gov/briefings-statements/statement-president-trump-paris-climateaccord/, accessed September 30, 2020. https://www.whitehouse.gov/briefings-statements /statement-president-trump-paris-climate-accord/

108 However, see Harald H. Koh, 'Triptych's End: A Better Framework to Evaluate 21st Century International Lawmaking' (2017) 126 Yale Law Journal Forum 338 at 358. 